\title{
EFEK PERPADUAN BEBERAPA TUMBUHAN LIAR DI SEKITAR AREA PERTANAMAN PADI DALAM MENARIK ARTHROPODA MUSUH ALAMI DAN HAMA
}

\author{
Lu'aili Addina*, Bagyo Yanuwiadi**, Zulfaidah Panata Gama** dan Amin Setyo Leksono** \\ *Mahasiswa Program S-2, Program Studi Biologi Fakultas MIPA Universitas Brawijaya Malang \\ **Jurusan Biologi Fakultas MIPA Universitas Brawijaya Malang
}

\begin{abstract}
This study aims to determine the interest Arthropoda against some wild mix consisting of Chromolaena odorata, Bidens pilosa., Echinochloa Cruss-galli, and Pistia stratiotes. This research is a semi experimental parameters observed were differences in the abundance of arthropods in each observation plot good plot consisting of some combination of wild plants (block refugia) and plot a block away from refugia based on spatial and temporal distribution. Observations using the "visual control" developed Freie and Manhart (1992). Achieved 9 order Arthropoda consists of 32 families were recorded visiting a mix of wild plants, the Coccinellidae, Carabidae, Staphylinidae, Chrysomelidae, Curculionidae, Coenagrionidae, Libellulidae, Tettigonidae, Gryllidae, Acrididae, Mantidae, Syrphidae, Drosophilidae, Tipulidae, Formicidae, Vespidae, Sphecidae, Ichneumonidae, Braconidae, Pyralidae, Papilionidae, Noctuidae, Nymphalidae, Alydidae, Pentatomidae, Reduviidae, Cicadellidae, Delphacidae, Flatidae, Tetragnathidae, and Oxyopidae. The mean abundance was highest in plots dominated by observation block refugia of the family Coccinellidae arthropods that act as natural enemies with a mean abundance reached 29 individuals per day. While the family Reduviidae which acts as a pest has the lowest with a mean abundance value of 1 individual per day. The analysis shows there are 6 families Arthropod natural enemies and pests that show distribution patterns are influenced by the presence of a mix of wild plants (the spatial distribution pattern) and different observation time (temporal distribution pattern), from the family Coccinellidae, Ichneumonidae, Braconidae, Acrididdae, Drosophilidae and Coreidae with a $P$ value $<0.05$.
\end{abstract}

Keywords : Refugia, Wild Plant, Arthropoda

\section{PENDAHULUAN}

Praktek pertanian mempunyai pengaruh yang sangat kuat terhadap keanekaragaman Arthropoda dalam suatu areal pertanaman padi (Triwidodo et al, 2001). Salah satu faktor yang sangat mudah mempengaruhi adalah penggunaan pestisida sintetik-organik berspektrum luas. Pestisida tersebut membunuh banyak jenis organisme bermanfaat, termasuk musuh alami hama (predator dan parasitoid) dan juga seranggaserangga netral, seperti serangga-serangga dan organisme lain yang hidup di air sawah. Serangga predator dan serangga lainnya selain hama lebih dahulu terbunuh oleh pestisida daripada serangga-serangga hama. Oleh sebab itu, penggunaan pestisida berspektrum lebar tidak akan menurunkan populasi hama, namun sebaliknya dapat meningkatkan populasi hama karena pestisida menghentikan proses pengendalian hama secara alami (Trisnaningsih et al, 2001).
Ekosistem padi merupakan ekosistem yang cukup kaya dengan keanekaragaman Arthropoda dan mampu memelihara ekosistem dalam kondisi yang relatif stabil. Salah satu indikator kestabilan ekosistem adalah tidak adanya jenis organisme yang populasinya menonjol atau meningkat, tanpa ada proses pengaturan populasi musuh alami yang dapat menghentikan peningkatan populasi tersebut. Keanekaragaman hayati Arthropoda pada ekosistem pertanian sudah ada sejak lama di Indonesia dan menunjukkan tingkat yang cukup tinggi (Sosromarsono et al, 2001). Terbentuknya mekanisme dan proses pengendalian alami di pesawahan untuk dapat berjalan dengan baik memerlukan waktu penyesuaian secara alami yang cukup lama (Nurindah et al, 2003).

Tumbuhan liar merupakan komponen agroekosistem yang penting, karena secara positif dapat mempengaruhi biologi dan dinamika musuh alami. Tumbuhan liar yang 
tumbuh di sekitar pertanaman tidak hanya berfungsi sebagai tempat berlindung dan pengungsian musuh alami ketika kondisi lingkungan tidak sesuai, tetapi juga menyediakan inang alternatif dan makanan tambahan bagi imago parasitoid seperti tepung sari dan nektar dari tumbuhan berbunga serta embun madu yang dihasilkan oleh ordo Homoptera (Altieri dan Nicholls 2004 dalam Yaherwandi et al, 2008).

Banyak penelitian memperlihatkan bahwa manipulasi tumbuhan liar dapat meningkatkan kelimpahan dan keanekaragaman musuh alami. Diantaranya peneletian Sukaromah et al (2006) yang menjelaskan bahwa beberapa serangga dari famili Coccinelidae memiliki ketertarikan yang cukup besar terhadap tumbuhan dari suku Asteraceae. Hal tersebut juga diperkuat dengan hasil penelitian Widiastutie (2000) yang melaporkan bahwa serangga famili Coccinellidae memiliki ketertarikan yang tinggi terhadap tanaman famili asteraceae terutama spesies Eupathorium odoratum sebesar $60 \%$ dan $45 \%$ dari jumlah serangga uji. Menurut Widiastutie (2000), juga disebutkan bahwa serangga famili Coccinellidae memiliki respon tercepat terhadap tanaman spesies Bidens pilosa. Dalam penelitian Nandini (2000) juga dilaporkan bahwa lalat kibar (Syrphidae) tertarik pada beberapa tumbuhan liar berbunga Stachytarpheta indica, Mimosa pudica, Bidens pilosa, dan Vernonia cinera. Selain itu, Beberapa tanaman air seperti semanggi (Marsilea crenata) dan kayu apu (Pistia stratiotes) juga mampu menarik serangga Adalia bipunctata dan Coccinella sp. yang merupakan salah satu serangga predator (Mukti, 2007). Berdasarkan penelitian di laboratorium oleh Karindah (2006), tanaman air Pistia stratiotes dapat menarik serangga Metioche vittaticollis lebih tinggi ketika dikombinasikan dengan tanaman Echinochloa cruss-galli, dimana Metioche vittaticollis merupakan serangga dalam famili Gryllidae yang termasuk dalam serangga yang berperan sebagai musuh alami. Beberapa penelitian tersebut memberikan informasi bahwa tumbuhan liar yang umumnya lebih dikenal dengan sebutan gulma, ternyata memiliki potensi sebagai penarik serangga-serangga yang berperan sebagai musuh alami yang dapat bermanfaat bagi proses pengendalian hama pada tanaman budidaya secara hayati.

\section{METODE PENELITIAN}

Penelitian ini dilakukan di lahan pertanian daerah Sawojajar II, Kecamatan Pakis, Kabupaten Malang. Arthropoda yang diperoleh dari lahan pertanian, selanjutnya diidentifikasi di Laboratorium Ekologi dan Diversitas Hewan Jurusan Biologi Fakultas Matematika dan Ilmu Pengetahuan Alam Universitas Brawijaya Malang. Penelitian dimulai pada bulan Agustus 2010 sampai bulan April 2011.

Penelitian ini merupakan penelitian semi eksperimental dengan parameter yang diamati adalah rata-rata kehadiran Arthropoda (baik itu yang berperan sebagai hama tanaman padi maupun musuh alaminya) terhadap plot yang terdiri dari perpaduan beberapa tumbuhan liar Chromolaena odorata, Bidens pilosa, Echinochloa cruss-galli, dan Pistia stratiotes (yang selanjutnya disebut dengan blok refugia) dan perbedaan kelimpahan Arthropoda pada masing-masing plot, pada plot yang berperan sebagai blok refugia maupun plot yang menjauhi blok refugia berdasarkan distribusi spasial dan temporal.

Tumbuhan liar yang terdiri dari Chromolaena odorata, Bidens pilosa, Echinochloa cruss-galli, dan Pistia stratiotes yang akan digunakan dalam penelitian ini, terlebih dahulu ditanam dalam polybag sebelum diletakkan di area persawahan. Komposisi masing-masing tumbuhan adalah sama. Persiapan ini dilakukan kurang lebih selama 3-4 minggu, yang bertujuan untuk mengaklimatisasi tumbuhan agar dapat beradaptasi di dalam polybag. Setelah tumbuhan pada kondisi normal, perpaduan dari keempat tumbuhan tersebut diletakkan pada petak yang berada di pojok sawah yang selanjutnya disebut sebagai blok refugia dengan ukuran $1 \times 1 \mathrm{~m}^{2}$. Penentuan letak blok refugia dilakukan dengan menggunakan prinsip purposive sampling yaitu penentuan sampling dengan tujuan khusus atau sampling yang dipertimbangkan berdasarkan tujuan penelitian. Petak-petak yang dijadikan sebagai plot pengamatan adalah petak yang menjauhi bagian tepi sawah dengan tujuan untuk meminimalkan pengaruh dari luar lingkungan di sekitar persawahan. Sedangkan lahan yang digunakan dalam penelitian ini dipilih lahan yang terdapat tumbuhan padi berumur $\pm 1,5$ bulan, dimana pada umur tersebut tanaman padi berpotensi terserang hama. 
Metode pengamatan yang digunakan adalah menggunakan metode visual control yang dikembangkan oleh Frei dan Manhart (1992). Metode visual control adalah metode pengamatan jarak jauh dengan mengamati secara langsung serangga yang mengunjungi blok refugia dan plot pengamatan rumpun padi yang menjauhi blok refugia, dengan jarak pengamatan 2 meter dan dilakukan dalam waktu-waktu tertentu. Kelebihan penggunaan metode pengamatan visual control adalah tidak dilakukan penangkapan Arthropoda, sehingga tidak mengganggu kehidupan Arthropoda terutama yang berkaitan dengan aktivitas musuh alami yang terdapat di sekitar area pertanaman padi tersebut.

Pengamatan dilakukan pada 4 plot pengamatan dengan jarak antar plot adalah 2 meter. Plot pertama adalah blok refugia yang terdapat perpaduan beberapa tumbuhan liar, sedangkan plot kedua, ketiga, dan keempat adalah plot pengamatan pada rumpun padi yang menjauhi blok refugia. Lama pengamatan pada masing-masing plot adalah 15 menit yang terdiri dari 4 periode pengamatan. Periode I dimulai pada pukul 07.00 sampai pukul 08.00, periode II dimulai pada pukul 09.00 sampai pukul 10.00, periode III dimulai pada pukul 12.00 sampai 13.00 , dan periode IV dimulai pada pukul 15.00 sampai pukul 16.00. Pengamatan dilakukan selama 15 hari.

Data kelimpahan Arthropoda yang mengunjungi plot pengamatan dianalisis dengan menggunakan metode statistik deskriptif yaitu dengan menggunakan Analisis Variansi (ANAVA) dengan rancangan faktorial dan uji $\mathrm{F}$ pada taraf signifikan $5 \%$ dengan kelimpahan individu pada setiap famili sebagai variabel respon dan masing-masing plot pengamatan sebagai variabel prediktor. Pola variasi spasial dan temporal dianalisis menggunakan analisis regresi. Penghitungan analisis menggunakan software Microsoft excel 2010, MINITAB 13, dan SPSS 16.

\section{HASIL DAN PEMBAHASAN}

Hasil pengamatan di area persawahan Sawojajar Malang menunjukkan bahwa kumpulan beberapa tumbuhan liar yang terdiri dari Chromolaena odorata, Bidens pilosa, Echinochloa cruss-galli, dan Pistia stratiotes, mampu menarik Arthropoda untuk datang dan mengunjungi tumbuhan-tumbuhan tersebut. Didapatkan 9 ordo Arthropoda yang terdiri dari 30 famili yang dicatat telah mengunjungi perpaduan tumbuhan liar, yaitu Coccinellidae, Carabidae, Staphylinidae, Chrysomelidae, Curculionidae, Coenagrionidae, Libellulidae, Tettigonidae, Gryllidae, Acrididae, Syrphidae, Drosophilidae, Tipulidae, Formicidae, Vespidae, Sphecidae, Ichneumonidae, Braconidae, Pyralidae, Papilionidae, Noctuidae, Nymphalidae, Coreidae, Pentatomidae, Reduviidae, Cicadellidae, Delphacidae, Flatidae, Tetragnathidae, dan Oxyopidae. Menurut Maisyaroh (2011) keberadaan perpaduan tumbuhan liar terbukti mampu menarik Arthropoda terutama yang berperan sebagai musuh alami, sehingga upaya konservasi tumbuhan liar sebagai refugia merupakan salah satu usaha yang potensial dalam rangka meningkatkan jumlah musuh alami dalam lahan pertanian.

Dari 30 famili Arthropoda yang ditemukan, terdapat 15 spesies yang mampu diidentifikasi yaitu, Menochilus sexmaculatus, Coccinella transversalis, Micraspis sp., Ophionea nigrofasciata, Paederus sp., Sympetrum sp., Orthetrum Sabina, Metioche vittaticolis, Xanthopimpla sp., Apanteles sp., Leptocorisa sp., Nephotettix virescens, Oxya chinensis, Tetragnatha sp., dan Oxyopes sp.

Tabel 1. Rerata Kelimpahan Arthropoda pada Plot Pengamatan

\begin{tabular}{|c|l|l|l|c|c|}
\hline \multirow{2}{*}{ NO. } & \multirow{2}{*}{ PERANAN } & \multirow{2}{*}{ ORDO } & \multirow{2}{*}{ FAMILI } & \multicolumn{2}{|c|}{$\begin{array}{c}\text { Rerata Kelimpahan } \\
\text { (individuari) }\end{array}$} \\
\cline { 5 - 6 } & & & & Blok Refugia & Kontrol \\
\hline 1. & Musuh Alami & Coleoptera & Coccinellidae & 29 & 6 \\
\hline 2. & Musuh Alami & Coleoptera & Staphylinidae & 9 & 1 \\
\hline 3. & Musuh Alami & Coleoptera & Carabidae & 2 & 1 \\
\hline 4. & Musuh Alami & Odonata & Coenagrionidae & 4 & 1 \\
\hline 5. & Musuh Alami & Odonata & Libellulidae & 21 & 4 \\
\hline 6. & Musuh Alami & Orthoptera & Tettigoniidae & 3 & 1 \\
\hline 7. & Musuh Alami & Orthoptera & Gryllidae & 2 & 1 \\
\hline 8. & Musuh Alami & Diptera & Syrphidae & 5 & 1 \\
\hline
\end{tabular}




\section{Lu'aili Addina}

\begin{tabular}{|r|l|l|l|c|c|}
\hline 9. & Musuh Alami & Hymenoptera & Formicidae & 26 & 3 \\
\hline 10. & Musuh Alami & Hymenoptera & Vespidae & 6 & 1 \\
\hline 11. & Musuh Alami & Hymenoptera & Sphecidae & 6 & 1 \\
\hline 12. & Musuh Alami & Hymenoptera & Ichneumonidae & 13 & 2 \\
\hline 13. & Musuh Alami & Hymenoptera & Braconidae & 11 & 1 \\
\hline 14. & Musuh Alami & Arachnida & Tetragnathidae & 3 & 1 \\
\hline 15. & Musuh Alami & Arachnida & Oxyopidae & 5 & 1 \\
\hline 16. & Hama & Coleoptera & Chrysomelidae & 18 & 4 \\
\hline 17. & Hama & Coleoptera & Curculionidae & 1 & 0 \\
\hline 18. & Hama & Orthoptera & Acrididae & 11 & 4 \\
\hline 19. & Hama & Diptera & Drosophilidae & 15 & 5 \\
\hline 20. & Hama & Diptera & Tipulidae & 1 & 0 \\
\hline 21. & Hama & Lepidoptera & Pyralidae & 2 & 1 \\
\hline 22. & Hama & Lepidoptera & Papilionidae & 1 & 0 \\
\hline 23. & Hama & Lepidoptera & Noctuidae & 1 & 0 \\
\hline 24. & Hama & Lepidoptera & Nymphalidae & 1 & 0 \\
\hline 25. & Hama & Hemiptera & Coreidae & 6 & 2 \\
\hline 26. & Hama & Hemiptera & Pentatomidae & 1 & 0 \\
\hline 27. & Hama & Hemiptera & Reduviidae & 1 & 0 \\
\hline 28. & Hama & Homoptera & Cicadellidae & 6 & 2 \\
\hline 29. & Hama & Homoptera & Delphacidae & 1 & 0 \\
\hline 30. & Hama & Homoptera & Flatidae & 1 & 0 \\
\hline
\end{tabular}

Data dalam Tabel 1 secara keseluruhan menunjukkan bahwa rerata kelimpahan Arthropoda pada plot pengamatan blok refugia lebih tinggi dibandingkan kelimpahan Artrhopoda pada plot pengamatan kontrol. Kelimpahan Arthropoda tertinggi pada plot pengamatan blok refugia didominasi oleh Arthropoda dari famili Coccinellidae dengan rerata kelimpahan mencapai 29 individu per hari. Sedangkan famili Reduviidae memiliki rerata kelimpahan terendah dengan nilai 1 individu per hari. Hal ini diduga perpaduan tumbuhan liar yang terdiri dari Chromolaena odorata, Bidens pilosa, Echinochloa crussgalli, dan Pistia stratiotes, yang mampu menarik famili Coccinellidae untuk mengunjungi tumbuhan-tumbuhan tersebut dikarenakan adanya respon dari seranggaserangga Coccinellidae terhadap sinyal-sinyal yang dikeluarkan oleh lingkungan di sekitarnya, termasuk dari tumbuhan-tumbuhan liar. Selain itu adanya preferensi kesesuaian inang yang dipilih juga merupakan salah satu penyebab ketertarikan Arthropoda terhadap inangnya. Dalam hal ini diduga tumbuhantumbuhan liar yang digunakan dalam penelitian mampu membuat famili Coccinellidae tertarik untuk menanggapi respon yang dikeluarkan oleh tumbuhantumbuhan liar tersebut. Menurut Altieri dan Nichols (2004) bahwa perilaku serangga menemukan tumbuhan seringkali berdasarkan mekanisme penciuman senyawa yang diuapkan oleh tumbuhan. Senyawa volatil yang dikeluarkan oleh tumbuhan uji merupakan stimulus efektif bagi banyak Arthropoda. 


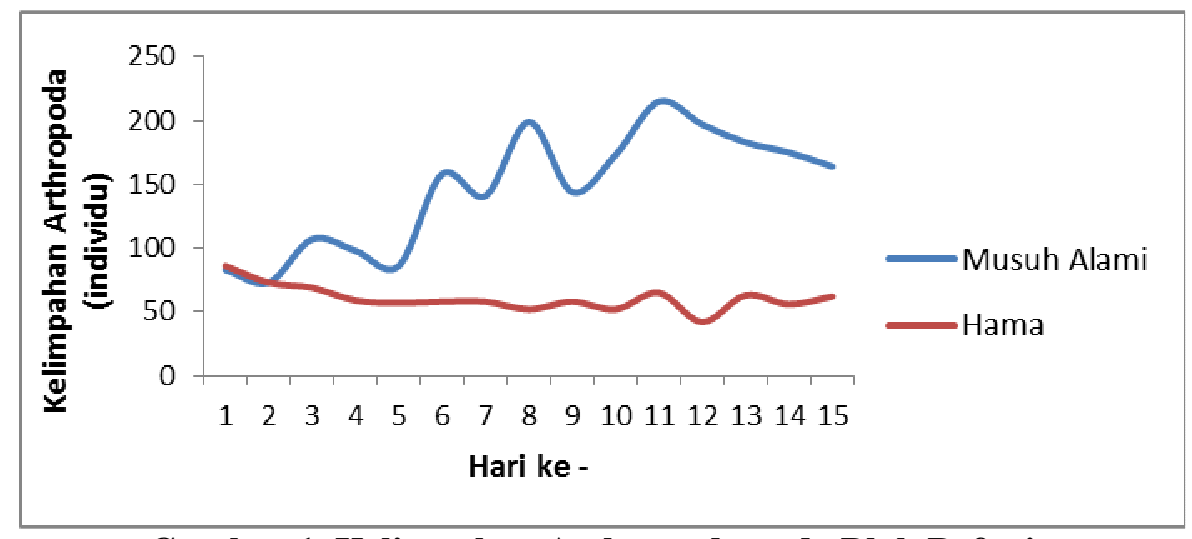

Gambar 1. Kelimpahan Arthropoda pada Blok Refugia

Berdasarkan gambar di atas (Gambar 1) menunjukkan kelimpahan Arthropoda pada plot pengamatan blok refugia selama 15 hari pengamatan. Grafik tersebut menunjukkan kehadiran Arthropoda pada plot pengamatan cenderung fluktuatif. Kelimpahan musuh alami mulai hari pertama pengamatan terlihat ada kecenderungan meningkat hingga pada titik puncak (hari ke 11) kemudian berangsurangsur menurun kembali. Jumlah kelimpahan musuh alami tertinggi didapatkan pada hari ke 11 pengamatan dengan jumlah 215 individu. Sedangkan kelimpahan Arthropoda yang berperan sebagai hama mulai dari hari pertama pengamatan hingga akhir pengamatan, jumlahnya cenderung menurun meski mengalami fluktuasi. Jumlah kehadiran tertinggi dperoleh pada hari pertama pengamatan dengan jumlah 86 individu. Jumlah kehadiran terendah diperoleh pada hari ke 12 pengamatan dengan jumlah 42 individu.

Grafik kelimpahan Arthropoda pada plot pengamatan blok refugia (Gambar 1), jika dibandingkan dengan grafik kelimpahan Arthropoda pada plot pengamatan kontrol, menunjukkan bahwa keberadaan perpaduan tumbuhan liar yang terdiri dari Chromolaena odorata, Bidens pilosa, Echinochloa crussgalli, dan Pistia stratiotes di area sekitar lahan padi, terbukti mampu menarik Arthropoda yang berperan sebagai musuh alami untuk hadir mengunjungi, sehingga dapat dikatakan bahwa perpaduan tumbuhan liar tersebut dapat digunakan sebagai habitat alternatif bagi Artrhopoda, terutama yang berperan sebagai musuh alami.

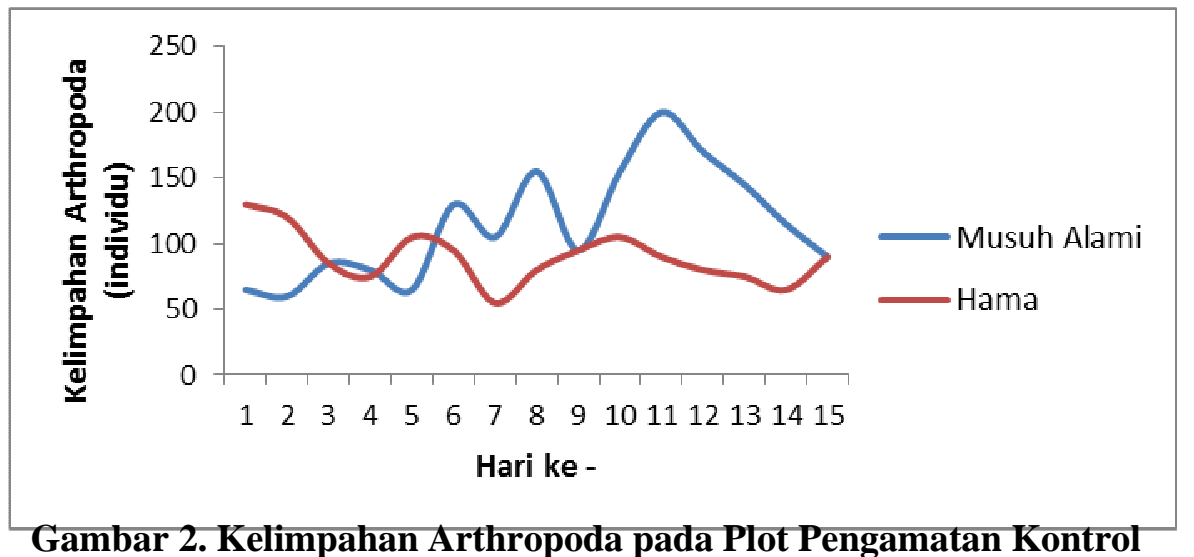

Pada gambar tersebut di atas (Gambar 2) memperlihatkan fluktuasi kelimpahan Arthropoda pada plot pengamatan kontrol, yang pada hari pertama hingga hari ketiga pengamatan menunjukkan kelimpahan Arthropoda yang berperan sebagai hama memiliki jumlah yang lebih tinggi dibandingkan kelimpahan Arthropoda yang berperan sebagai musuh alami. Namun, seiring dengan semakin meningkatnya kelimpahan musuh alami, berbanding terbalik dengan kelimpahan Arthropoda yang berperan sebagai hama, yang jumlahnya semakin menurun. Hal tersebut menunjukkan adanya proses pengendalian hayati secara alami yang terjadi dalam agroekosistem tersebut yang 
berhubungan dengan rantai makanan dalam suatu ekosistem tertentu. Hal ini sesuai dengan konsep ekologi yang menyebutkan bahwa terjadi proses alami dan interaksi-interaksi biologi yang dapat mengoptimalkan sinergi fungsi dari komponen-komponennya, yaitu dengan terjaganya perkembangan populasi herbivora melalui peningkatan peran Arthropoda predator dan antagonis (Nurindah, 2006).

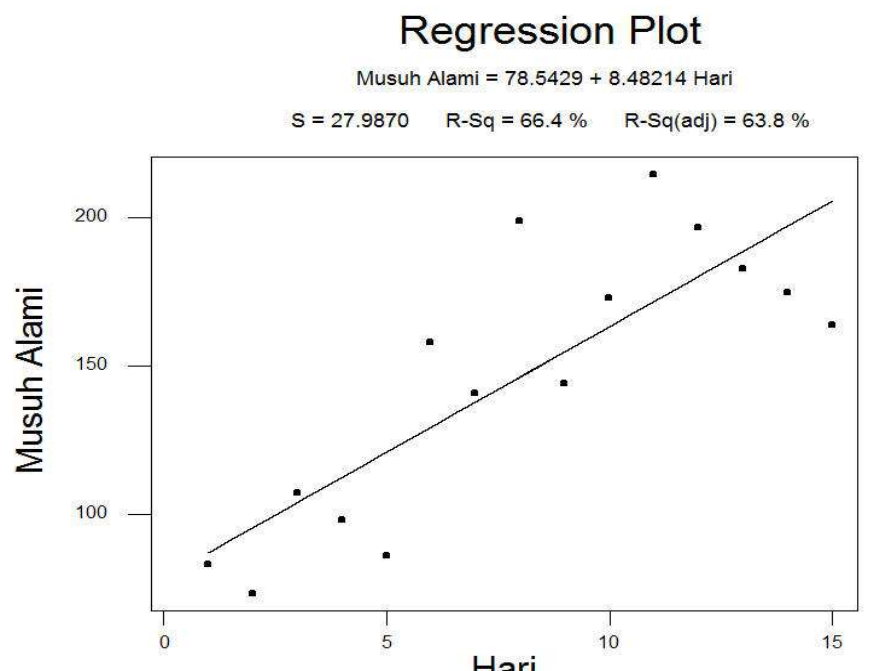

Gambar 3. Regresi linear kehadirăharimusuh alami selama 15 hari pengamatan

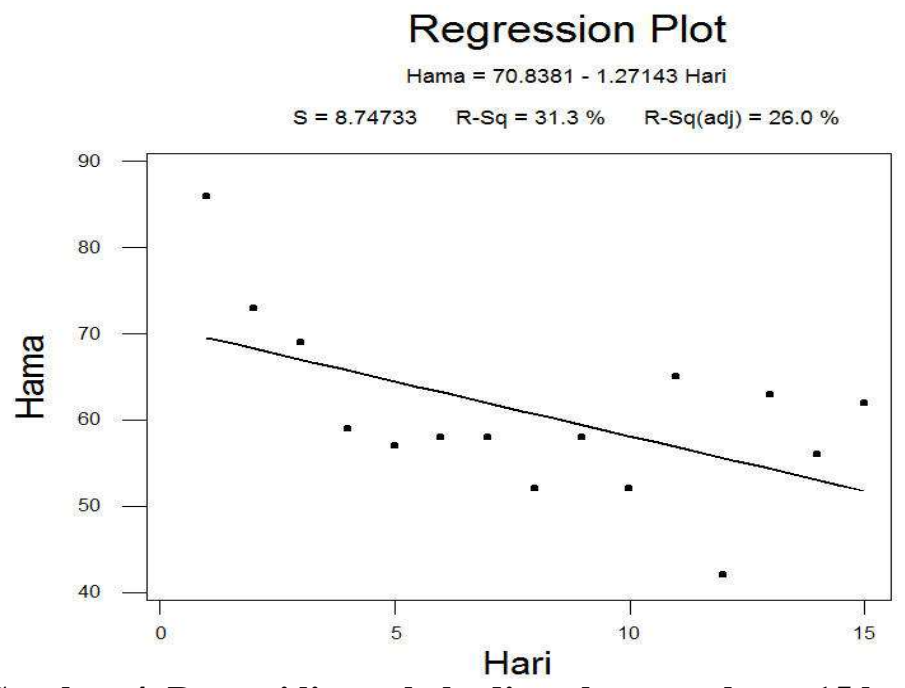

Gambar 4. Regresi linear kehadiran hama selama 15 hari pengamatan

Berdasarkan analisis regresi terhadap jumlah kelimpahan Arthropoda hama selama 15 hari menunjukkan bahwa nilai koefisien regresi sebesar -1,271. Hal ini menunjukkan bahwa jumlah kelimpahan hama di lahan pengamatan selama 15 hari semakin menurun, seperti terlihat pada grafik regresi di bawah ini (Gambar 4). Jumlah kelimpahan Arthropoda musuh alami yang semakin meningkat selama
15 hari pengamatan, diimbangi dengan jumlah kelimpahan Arthropoda hama yang semakin menurun. Hal ini berkaitan dengan pola rantai makanan yang terjadi pada suatu habitat tertentu. Musuh alami yang berperan sebagai konsumen tingkat kedua pada rantai makanan, mampu menekan jumlah hama yang berperan sebagai konsumen tingkat pertama (Heong et al, 1991). 
Keberadaan masing-masing jenis Arthropoda yang berbeda tersebut, akan saling melengkapi dalam suatu ekosistem pertanian sehingga dapat menciptakan kestabilan ekosistem tanpa adanya dominasi populasi oleh suatu organisme tertentu. Menurut Mahrub (1998) dalam Dadi (2010), kestabilan komunitas didukung dengan terciptanya kondisi saling melengkapi antar komponen dalam komunitas yang melaksanakan fungsi berbeda dan berinteraksi secara sinergis, sehingga bila kestabilan menurun, maka kehidupan ekosistem akan terganggu.

Berdasarkan uji statistik Anava, didapatkan hasil bahwa jumlah kelimpahan Arthropoda musuh alami yang hadir pada tiap plot terdapat perbedaan secara nyata dengan nilai $\mathrm{P}=0,001(\mathrm{P}<0,05)$, begitu juga dengan pola distribusi spasial Arthropoda hama juga menunjukkan perbedaan yang nyata dengan nilai $\mathrm{P}=0,000(\mathrm{P}<0,05)$. Hal ini menunjukkan bahwa keberadaan perpaduan beberapa tumbuhan liar di area persawahan memiliki efek mampu menarik Arthropoda untuk mengunjungi tumbuhan liar tersebut. Uji statistik Anava terhadap pola distribusi temporal pada Arthropoda musuh alami juga menunjukkan perbedaan yang nyata dengan nilai $\mathrm{P}=0,000 \quad(\mathrm{P}<0,05)$. Sedangkan uji statistik Anava Sedangkan terhadap pola distribusi temporal Arthropoda hama tidak menunjukkan perbedaan secara nyata, dengan nilai $\mathrm{P}=0,253(\mathrm{P}>0,05)$. Ini menunjukkan bahwa masing-masing Arthropoda memiliki waktu-waktu biologis tertentu yang berbeda tiap jenisnya sehingga mampu mempengaruhi jumlah kelimpahan Arthropoda pada tiap-tiap periode

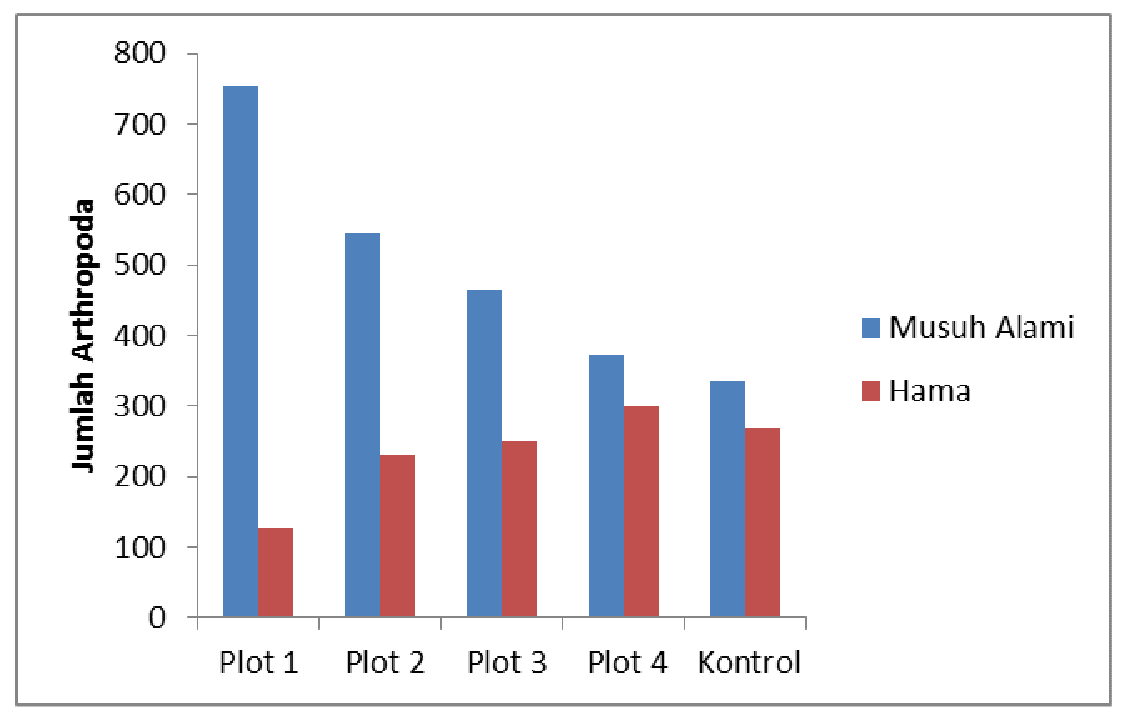

Gambar 5. Pola Distribusi Spasial Arthropoda

Berdasarkan grafik di atas (Gambar 5) menunjukkan bahwa pola distribusi spasial Arthropoda dalam penelitian ini semakin menjauhi blok refugia (plot 1), rerata kelimpahan Arthropoda yang berperan sebagai musuh alami semakin menurun dan sebaliknya yang terjadi pada rerata kelimpahan hama yaitu semakin menjauhi blok refugia, semakin meningkat. Hal tersebut bisa disebabkan karena hama diduga menjauhi blok refugia karena keberadaan musuh alami yang mendominasi blok refugia.
Kemampuan masing-masing individu serangga untuk melakukan persebaran dalam ruang dan waktu tertentu merupakan gabungan dari sifat fisik, biomorfologi dan kondisi lingkungan, sehingga dalam satu jenis Arthropodapun dapat menunjukkan pola variasi spasial dan temporal yang berbeda. Menurut Leksono (2007) dalam rangka seleksi habitat serangga selalu mempertimbangkan ketersediaan makanan, penghindaran dari kompetitor dan penghindaran dari predator. 


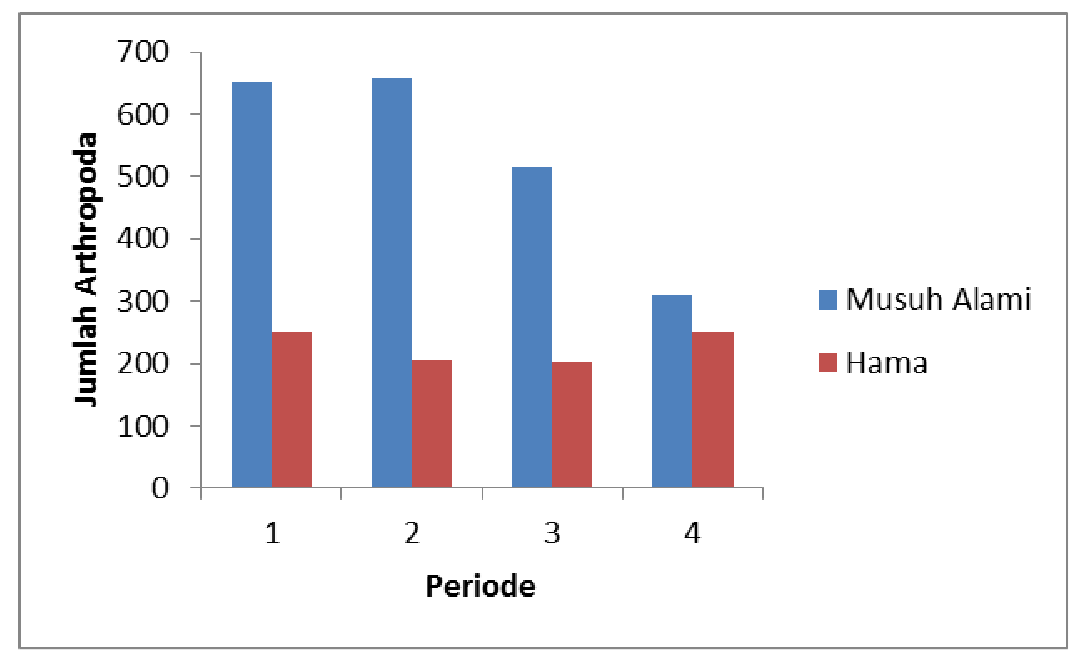

Gambar 6. Pola Distribusi Temporal Arthropoda

Melalui gambar grafik pola distribusi temporal Arthropoda (gambar 6), dapat diketahui bahwa pola distribusi temporal pada musuh alami menunjukkan bahwa semakin sore, rerata kelimpahan Arthropoda yang berperan sebagai musuh alami semakin menurun, sedangkan rerata kelimpahan Arthropoda hama ada kecenderungan meningkat meski tidak terlalu signifikan perbedaannya. Hal ini diduga karena pola hidup serta karakteristik morfologi dan fisiologi Arthropoda musuh alami yang dicatat dalam penelitian ini memiliki kesesuain kondisi di saat pengamatan pada waktu pagi hari, sehingga keberadaan musuh alami tersebut mampu mempengaruhi keberadaan hama.

Distribusi serangga secara spasial maupun temporal berkaitan erat dengan siklus hidup, karakteristik morfologi jenis,dan kondisi klimatik pada saat jenis tersebut memilih habitatnya selain waktu mencari mangsa, reproduksi dan pengenalan inang (Schoenly et al, 2003). Berdasarkan hasil analisis menunjukkan bahwa hanya Arthropoda tertentu yang memiliki pola distribusi spasial atau temporal. Pada tabel berikut disajikan hasil analisis data Arthropoda terhadap pola distribusi spasial maupun temporal :

Tabel 2. Data Distribusi Spasial dan Distribusi Temporal Arthropoda

\begin{tabular}{|c|c|c|c|c|c|}
\hline No. & Famili & Distribusi & $\mathbf{F}$ & Sig & $\begin{array}{c}\text { R Square } \\
(\%)\end{array}$ \\
\hline \multirow{3}{*}{1.} & \multirow{3}{*}{ Coccinellidae } & Spasial & 2,218 & 0,099 & \multirow{3}{*}{36,4} \\
\hline & & Temporal & 11,715 & 0,000 & \\
\hline & & $\begin{array}{l}\text { Spasial \& } \\
\text { Temporal }\end{array}$ & 14,422 & 0,000 & \\
\hline \multirow{3}{*}{2.} & \multirow{3}{*}{ Ichneumonidae } & Spasial & 1,370 & 0,264 & \multirow{3}{*}{36,1} \\
\hline & & Temporal & 7,538 & 0,000 & \\
\hline & & $\begin{array}{l}\text { Spasial \& } \\
\text { Temporal }\end{array}$ & 14,276 & 0,000 & \\
\hline \multirow{3}{*}{3.} & \multirow{3}{*}{ Braconidae } & Spasial & 2,698 & 0,057 & \multirow{3}{*}{38,4} \\
\hline & & Temporal & 5,999 & 0,002 & \\
\hline & & $\begin{array}{l}\text { Spasial \& } \\
\text { Temporal }\end{array}$ & 15,624 & 0,000 & \\
\hline \multirow{3}{*}{4.} & \multirow{3}{*}{ Acrididae } & Spasial & 16,278 & 0,000 & \multirow{3}{*}{50,4} \\
\hline & & Temporal & 0,772 & 0,516 & \\
\hline & & $\begin{array}{l}\text { Spasial \& } \\
\text { Temporal }\end{array}$ & 24,910 & 0,000 & \\
\hline 5. & Drosophilidae & Spasial & 4,308 & 0,009 & 26,0 \\
\hline
\end{tabular}




\begin{tabular}{|c|c|c|c|c|c|}
\hline & & Temporal & 11,427 & 0,000 & \\
\hline & & $\begin{array}{l}\text { Spasial \& } \\
\text { Temporal }\end{array}$ & 9,256 & 0,000 & \\
\hline \multirow{3}{*}{6.} & \multirow{3}{*}{ Coreidae } & Spasial & 10,973 & 0,000 & \multirow{3}{*}{44,6} \\
\hline & & Temporal & 2,650 & 0,060 & \\
\hline & & $\begin{array}{l}\text { Spasial \& } \\
\text { Temporal }\end{array}$ & 19,919 & 0,000 & \\
\hline \multirow{3}{*}{7.} & \multirow{3}{*}{ Musuh Alami } & Spasial & 6,679 & 0,001 & \multirow{3}{*}{55,8} \\
\hline & & Temporal & 8,763 & 0,000 & \\
\hline & & $\begin{array}{l}\text { Spasial \& } \\
\text { Temporal }\end{array}$ & 30,674 & 0,000 & \\
\hline \multirow{3}{*}{8.} & \multirow{3}{*}{ Hama } & Spasial & 30,988 & 0,000 & \multirow{3}{*}{61,9} \\
\hline & & Temporal & 1,408 & 0,253 & \\
\hline & & $\begin{array}{l}\text { Spasial \& } \\
\text { Temporal }\end{array}$ & 39,148 & 0,000 & \\
\hline
\end{tabular}

Tabel di atas merupakan nilai hasil analisis variansi dan regresi yang menunjukkan perbedaan nyata pada tiap pola distribusi, baik itu pola distribusi spasial maupun pola distribusi temporalnya. Haasil analisis yang tertulis pada tabel di atas menunjukkan familifamili Arthropoda yang pola distribusinya dipengaruhi oleh keberadaan perpaduan tumbuhan liar yang digunakan dalam penelitian ini.

Famili Coccinellidae memiliki nilai RSquare sebesar 36,4\%. Artinya jumlah kelimpahan famili Coccinellidae di lahan pengamatan, sebesar $36,4 \%$ dipengaruhi oleh faktor pola distribusi spasial dan temporal, sedangkan selebihnya dipengaruhi oleh faktor lain seperti faktor abiotik yang meliputi suhu, kelembaban, intensitas cahaya, dan sebagainya. Hasil uji Anova dan BNT (5\%) menunjukkan bahwa famili Coccinelidae tidak memiliki pola distribusi spasial $(\mathrm{Sig}=0,099)$ tetapi menunjukkan pola distribusi temporal (Sig =0,000). Pada family Ichneumonidae, nilai R-Square menunjukkan angka $36,1 \%$, artinya jumlah kelimpahan famili Ichneumonidae selama pengamatan dipengaruhi oleh pola distribusi spasial dan temporal sebesar $36,1 \%$. Sedangkan sebesar $63,9 \%$ sisanya dipengaruhi oleh faktor lain di luar faktor kedua pola distribusi tersebut. Berdasarkan hasil analisis Anava dan BNT (5\%) bahwa jumlah kehadiran famili Ichneumonidae selama pengamatan tidak menunjukkan pola distribusi spasial $(\mathrm{P}=$ 0,264), namun menunjukkan pola distribusi temporal $(\mathrm{P}=0,000)$. famili Braconidae memiliki nilai $\mathrm{R}$-square $38,4 \%$, artinya jumlah kelimpahan famili Braconidae selama pengamatan dipengaruhi oleh pola distribusi spasial dan temporal sebesar $38,4 \%$, sedangkan sisanya senilai $61,6 \%$ dipengaruhi oleh faktor diluar faktor pola distribusi spasial dan pola distribusi temporal.

Famili Acrididae memiliki nilai RSquare $50,4 \%$, artinya jumlah kelimpahan famili Acrididae selama pengamatan dipengaruhi oleh faktor pola distribusi spasial dan temporal sebesar 50,4\%, sedangkan selebihnya senilai 49,6\% dipengaruhi oleh faktor luar selain faktor pola distribusi spasial dan temporal. Berdasarkan uji BNT (5\%), jumlah kelimpahan famili Acrididae menunjukkan pola distribusi spasial $(\mathrm{Sig}=$ $0,000)$ dan tidak menunjukkan pola distribusi temporal $(\mathrm{Sig}=0,516)$. Famili Drosophilidae nilai R-Square menunjukkan angka 26,0\%, artinya jumlah kelimpahan famili Drosophilidae selama pengamatan dipengaruhi oleh pola distribusi spasial dan temporal sebesar 26,0\%. Sedangkan sebesar $74,0 \%$ sisanya dipengaruhi oleh faktor lain di luar faktor kedua pola distribusi tersebut. Berdasarkan hasil analisis Anava dan BNT (5\%) bahwa jumlah kehadiran famili Drosophilidae selama pengamatan menunjukkan pola distribusi spasial $(\mathrm{P}=$ 0,009) dan menunjukkan pola distribusi temporal $(\mathrm{P}=0,000)$. famili Coreidae memiliki nilai R-Square 44,6\%, artinya jumlah kelimpahan famili Coreidae selama pengamatan dipengaruhi oleh faktor pola distribusi spasial dan temporal sebesar 44,6\%, sedangkan selebihnya senilai $55,4 \%$ dipengaruhi oleh faktor luar selain faktor pola distribusi spasial dan temporal. Berdasarkan uji BNT (5\%), jumlah kelimpahan famili 
Coreidae menunjukkan pola distribusi spasial $(\mathrm{Sig}=0,000)$ dan tidak menunjukkan pola distribusi temporal $(\mathrm{Sig}=0,060)$.

\section{KESIMPULAN}

Didapatkan 9 ordo Arthropoda yang terdiri dari 32 famili yang dicatat telah mengunjungi perpaduan tumbuhan liar, yaitu Coccinellidae, Carabidae, Staphylinidae, Chrysomelidae, Curculionidae, Coenagrionidae, Libellulidae, Tettigonidae, Gryllidae, Acrididae, Mantidae, Syrphidae, Drosophilidae, Tipulidae, Formicidae, Vespidae, Sphecidae, Ichneumonidae, Braconidae, Pyralidae, Papilionidae, Noctuidae, Nymphalidae, Alydidae, Pentatomidae, Reduviidae, Cicadellidae, Delphacidae, Flatidae, Tetragnathidae, dan Oxyopidae.

Rerata kelimpahan tertinggi pada plot pengamatan blok refugia didominasi oleh Arthropoda dari famili Coccinellidae yang berperan sebagai musuh alami dengan rerata kelimpahan mencapai 29 individu per hari. Sedangkan famili Reduviidae yang berperan sebagai hama memiliki rerata kelimpahan terendah dengan nilai 1 individu per hari.

Hasil analisis menunjukkan terdapat

6 famili Arthropoda musuh alami dan hama yang menunjukkan pola distribusinya dipengaruhi oleh keberadaan perpaduan tumbuhan liar tersebut (pola distribusi spasial) dan waktu pengamatan yang berbeda (pola distribusi temporal), yaitu dari famili Coccinellidae, Ichneumonidae, Braconidae, Acrididdae, Drosophilidae, dan Coreidae dengan nilai $\mathrm{P}<0,05$.

\section{DAFTAR PUSTAKA}

Altieri and Nicholls. 2004. Biodiversity and Pest Management in Agroecosystems. Food Product Press. 236 p.

Dadi. 2010. Potensi Agroforestri Pendukung Eksistensi Arthropoda Predator Wereng Padi di Ekosistem Sawah. Disertasi. Program Studi Ilmu-Ilmu Pertanian. Program Pasca Sarjana Fakultas Pertanian. Universitas Brawijaya. Malang

Frei, G. dan C. Manhart. 1992. Nützlinge und Schadlinge an Kunstlich Angelegten Ackerkraustreifen in Getreidefeldern. Agrarökologie 4.
Heong, K.L., G.B. Aquino and A.T. Barrion. 1991. Arthropod Community Structures of Rice Ecosistems in the Philippines. Bul. of Entomol. Res. 81: 407-416

Karindah, S. 2006. The Use of Weed Plant Species to Enhance The Conservation of Metioche vittaticollis (Stai) (Orthoptera: Gryllidae), A generalist Predator of Rice Hopper. Dissertation. Agricultulture Science Pest And Plant Disease. Brawijaya University. Post Graduate Program. Malang.

Leksono, A. S. 2007. Ekologi : pendekatan Deskriptif dan Kuantitatif. Bayumedia Publishing. Malang.

Maisyaroh, W., B. Yanuwiadi, A.S. Leksono and Zulfaidah P.G. 2011. Spatial and Temporal Distribution of Natural Enemies Visiting Refugia in A Paddy Field Area in Malang. Agrivita Vol. 34 No. 1. February 2012. Pp 67-74.

Nandini, S. 2000. Preferensi Lalat Kibar (Syrpidae) Terhadap Beberapa Jenis Gulma Berbunga. Skripsi Jurusan Biologi FMIPA Universitas Brawijaya. Malang.

Nurindah dan Marwoto, 2003. Pemanfaatan Parasitoid Telur dalam Pengendalian Hama. Balittas. Malang. 25 hal

Nurindah. 2006. Pengelolaan Agroekosistem dalam Pengendalian Hama. Perspektif Vol 5 No 2, Desember 2006 : 78-85

Schoenly, K.G., I.T. Domingo and A.T. Barrion. 2003. Determining Optimal Quadrat Sizes for Invertebrate Communities in Agrobiodiversity Studies: A Case Study from Tropical Irrigated Rice. Environ. Entomol. 32(5): 929-938.

Sosromarsono, S, K. Untung. 2001. Keanekaragaman Hayati Arthropoda Predator dan Parasitoid di Indonesia Serta Pemanfaatannya. Dalam Kumpulan Prosiding Simposium Keanekaragaman Hayati Arthropoda Pada Sistem Produksi Pertanian Cipayung 16 - 18 Oktober 2000. Bogor.

Sukaromah, dan Yanuwiadi. 2006. Preferensi Serangga Famili Coccinellidae untuk Memilih Kombinasi Tumbuhan Famili 
Asteraceae. Bioscientiae. Vol. 3. No.1. hal. 30-38

Triwidodo, H. A. Rizali dan D. Buchori. 2001. Keanekaragaman Serangga dan Peranannya di Daerah Persawahan di Taman Nasional Gunung Halimun Desa Malasari Kabupaten Bogor Jawa Barat. Dalam Kumpulan Prosiding simposium Keanekaragaman Hayati Arthropoda Pada Sistem Produksi Pertanian Cipayung 16 - 18 Oktober 2000. Bogor.

Widiastuti, Agustina. 2000. Uji Preferensi Serangga Coccinelidae Pada Tanaman
Familia Asteraceae. Skripsi. FMIPA. Universitas Brawijaya. Malang

Yaherwandi, dan Usra Syam. 2008. Struktur Komunitas Hymenoptera Parasitoid Yang Beasosiasi Dengan Hama Utama Tanaman Cruciferae Dan Tumbuhan Liar Pada Tipe Lanskap Pertanian Berbeda. Fakultas Pertanian Universitas Andalas. Padang.

http://repository.unand.ac.id/728/1/Artik el_Yaherwandi.doc. Diakses tanggal 15 Desember

2010. 